\title{
Comparative pollen spectra of Tetragonisca angustula (Apidae, Meliponini) from the Lower Amazon (N Brazil) and caatinga (NE Brazil)
}

\author{
Jaílson S. de NovaIs ${ }^{1,2}$, Ana Cristina A. GARCÊZ ${ }^{1}$, Maria Lúcia ABsY ${ }^{2}$, \\ Francisco de Assis R. dos SAntos ${ }^{3}$ \\ ${ }^{1}$ Centro de Formação Interdisciplinar and Laboratório de Botânica Taxonômica, Universidade Federal do Oeste do Pará, \\ Rua Vera Paz, s/n, Salé, 68035-110, Santarém, Pará, Brazil \\ ${ }^{2}$ Laboratório de Palinologia, Coordenação de Biodiversidade, Instituto Nacional de Pesquisas da Amazônia, Av. André \\ Araújo, 2.936, Petrópolis, 69067-375, Manaus, Amazonas, Brazil \\ ${ }^{3}$ Laboratório de Micromorfologia Vegetal, Departamento de Ciências Biológicas, Universidade Estadual de Feira de \\ Santana, Av. Transnordestina, s/n, 44036-900, Feira de Santana, Bahia, Brazil
}

Received 18 January 2014 - Revised 26 September 2014 - Accepted 21 October 2014

\begin{abstract}
Tetragonisca angustula is a stingless bee species widely distributed in Brazil. Past studies have shown a rich native flora supplying this meliponine with pollen and nectar. The aim of this study was to compare the food provisions of $T$. angustula in two areas in the Lower Amazon mesoregion in the state of Pará and two areas of caatinga vegetation in the state of Bahia, Brazil. We used a published data set of 57 samples of honey and 46 samples of pollen stored in colonies of T. angustula. The honeys from the Lower Amazon and from the caatinga displayed 23 and 16 pollen types with frequency higher than $>10 \%$, respectively, with emphasis on the families Fabaceae, Solanaceae, and Urticaceae. In the pollen stored samples, 18 and 11 pollen types were found, respectively. Cluster analyses (Dice similarity) performed with these published pollen spectra of the honeys grouped the samples from each geographic region with higher similarity than the analyses performed with the pollen spectra of the stored pollen.
\end{abstract}

cluster analysis / Dice similarity / entomopalynology / honey / melissopalynology / pollen stored / stingless bees

\section{INTRODUCTION}

The Amazon Forest and the caatinga (dry forest) together form more than 5 million $\mathrm{km}^{2}$, equivalent to approximately $60 \%$ of the Brazilian territory (IBGE 2004). The Amazon Forest, extending over eight Latin-American countries in addition to Brazil, is the largest tropical rainforest of the planet, with a high precipitation level irregularly

Electronic supplementary material The online version of this article (doi:10.1007/s13592-014-0332-z) contains supplementary material, which is available to authorized users.

Corresponding author: J. Novais, novais.js@gmail.com

Manuscript editor: James Nieh distributed in time and space (Fisch et al. 1998). In contrast, the seasonally dry forests of the caatinga encompass different mosaics of vegetation subjected to a rigorous precipitation deficit (Prado 2003). Disturbances in both of these biomes have threatened native bee populations and hindered the environmental services provided by them (Freitas et al. 2009; Maia-Silva et al. 2012).

Recently, in independent palynological studies, we investigated the pollen spectra of honey and pollen stored by Tetragonisca angustula (Latreille, 1811) (Apidae: Meliponini) from Amazonian (Novais and Absy 2013; Novais and Absy in press) and caatinga (Novais et al. 2013, 2014) areas.

In this manuscript, we performed a comparative palynological analysis of the food provisions 
of T. angustula based on the published data mentioned above. The data on the pollen types found has been previously published but not qualitatively compared. With this study, we compiled the data set of plants foraged by T. angustula in two biomes (Amazon and caatinga) and also perform a cluster analysis aiming to better understand the similarity of pollen diet of this species in different regions in Brazil, one wet and another dry.

\section{MATERIALS AND METHODS}

\subsection{Study sites}

We used data obtained from four study sites: two located in the Lower Amazon mesoregion (Pará State, $\mathrm{N}$ Brazil) and two areas in the caatinga (Bahia State, NE Brazil) (Figure 1). Further information about these areas can be found in Novais and Absy (2013) and Novais et al. $(2013,2014)$.

\subsection{Collection, laboratory processing, and palynological analysis}

In total, 103 samples were studied: 57 samples of honey and 46 samples of pollen stored by T. angustula . The samples were collected in between September 2010 and January 2012 in the study sites of the Lower Amazon [Belterra (16 and 15 samples of honey and pollen, respectively) and Santarém (14 and 8 samples)] and in the caatinga [Itaberaba (13 and 10 samples of honey and pollen, respectively) and Ruy Barbosa (14 and 13 samples)] (Novais and Absy 2013; Novais et al. in press; Novais and Absy 2013, 2014).

The protocol for the collection of material, the laboratory procedures adopted, and the qualitative and quantitative palynological analysis performed were previously described by Novais and Absy (2013) and Novais and Absy (2013). The technique of acetolysis (Erdtman 1960) was used to process all the samples. For the purpose of this study, a sample consists of $5 \mathrm{~mL}$ of honey or 2-3 g of stored pollen, collected from one colony of $T$. angustula in each study site. After chemical processing, four glass slides were prepared and at least 500 pollen grains per sample were identified and quantified. From these data, the following frequency classes were established, as proposed by Louveaux et al. (1978): predominant pollen ( $>45 \%$ of the grains counted in a sample), secondary pollen (16-45\%), important minor pollen (3-15\%), and minor pollen $(<3 \%)$.

\subsection{Comparative analysis}

Comparative analysis was performed with the pollen spectra obtained, considering only the pollen types with frequencies higher than $10 \%$ in at least one of the samples analyzed because these types represent the most significant floral resources for the bees (Ramalho et al. 1985). We have not included in this analysis pollen types which frequencies were lower than $10 \%$ in all samples.
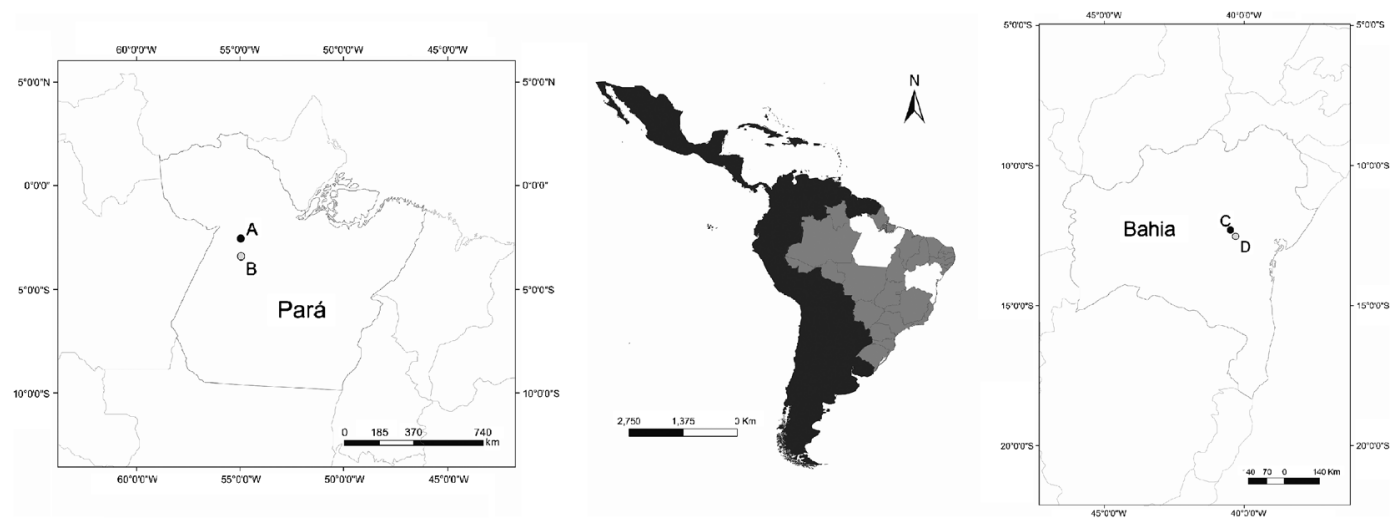

Figure 1. Location of the study sites in the Lower Amazon (map to the left) and in the caatinga (map to the right). In the map of the South America, in the center, Brazil is colored in gray, with emphasis on the states of Pará, in the north region, and Bahia, in the northeast region. The municipalities where the study was performed are represented by letters: $A$ Santarém, $B$ Belterra, $C$ Ruy Barbosa, $D$ Itaberaba. 
We performed a cluster analysis, using the Dice similarity coefficient (McCune and Grace 2002), to evaluate the formation of groups among the samples studied based on the pollen types identified in the samples. For the honeys, the 57 samples and the 36 pollen types identified were considered for the presence-absence data matrix (Hammer et al. 2001). Similarly, for the stored pollen, the 46 samples and the 29 pollen types identified were used for the data matrix. Therefore, we evaluated the presence of structured patterns, considering the period of collection and the different sampling areas. This analysis considered only the presence of the pollen types in the individual samples, disregarding the absence of a given pollen type as an indication of similarity.

The similarity analysis was performed with the software PAST-PAlaeontological STatistics, version 2.16 (Hammer et al. 2001). The climatic data of the study sites were obtained from the Brazilian National Institute of Meteorology (Instituto Nacional de Meteorologia, INMET 2013), except for the municipality of Ruy Barbosa, Bahia, where there is no meteorological station to record such data. A given month was considered dry when the total monthly precipitation, in millimeters, was equal to or lower than double the mean monthly temperature, expressed in degrees Celsius $(P \leq 2 T)$ (Bagnouls and Gaussen 1962).

\section{RESULTS}

\subsection{General considerations of the pollen spectra and the most representative pollen types}

The honey samples revealed a higher number of representative pollen types (those with a frequency higher than $10 \%$ in at least one sample) than the pollen stored samples. The honeys from Santarém, PA (17 pollen types) recorded the highest number of pollen types, followed by Ruy Barbosa, BA (14), Belterra, PA (12), and Itaberaba, BA (10) (Table I). For the pollen stored samples, Belterra, PA (11 pollen types) stood out among the municipalities, followed by Santarém, PA (10), Itaberaba, BA (9), and Ruy Barbosa, BA (7) (Table II).
In total, the honeys from the Amazonian study sites displayed 23 representative pollen types, representing 15 botanical families. In decreasing order, Warszewiczia coccinea, Microtea, Byrsonima, Cecropia, and Borreria verticillata occurred in more than $50 \%$ of the samples (Figure 2a). In the honeys from the caatinga, 16 pollen types and 11 botanical families were recorded, from which Prosopis juliflora, Solanum, Heteropterys, and Schinus were the most commonly observed pollen types (Figure $2 b$ ).

The pollen stored samples from the Amazonian study sites, in contrast, displayed 18 representative pollen types, representing 17 botanical families. The pollen types Cecropia and $B$. verticillata occurred in more than $50 \%$ of the samples (Figure 3a). The pollen stored samples from the caatinga revealed 11 pollen types and seven botanical families. Of these types, the most frequent were P. juliflora, Solanum, Senna macranthera, Brosimum, and Heteropterys (Figure 3b).

The honey samples from the Lower Amazon displayed eight pollen types classified as "predominant pollen": B. verticillata, Byrsonima, Cecropia, Chamaecrista, Clidemia hirta, Diodia, Solanum, and W. coccinea (Table I).

In contrast, the honeys from the caatinga revealed five predominant pollen types: Cecropia, Gomphrena demissa, P. juliflora, Schinus, and Solanum (Table I). Furthermore, we emphasize that the pollen types Cecropia and Solanum were part, as predominant pollen types, of the foraging behavior of $T$. angustula in both the Lower Amazon and the Bahian caatinga (Table I and Figure 2).

The pollen stored samples of T. angustula from the Lower Amazon revealed the following predominant pollen types: Byrsonima, Cecropia, C. hirta, Davilla kunthii, Eriope, Myrcia, and Vismia guianensis (Table II).

The pollen stored samples from the caatinga revealed seven predominant pollen types: Brosimum, Caesalpinioideae type, P. juliflora, Schinus, S. macranthera, Solanum, and Waltheria (Table II). No predominant pollen type occurred simultaneously in the pollen stored samples from both of the biomes. 


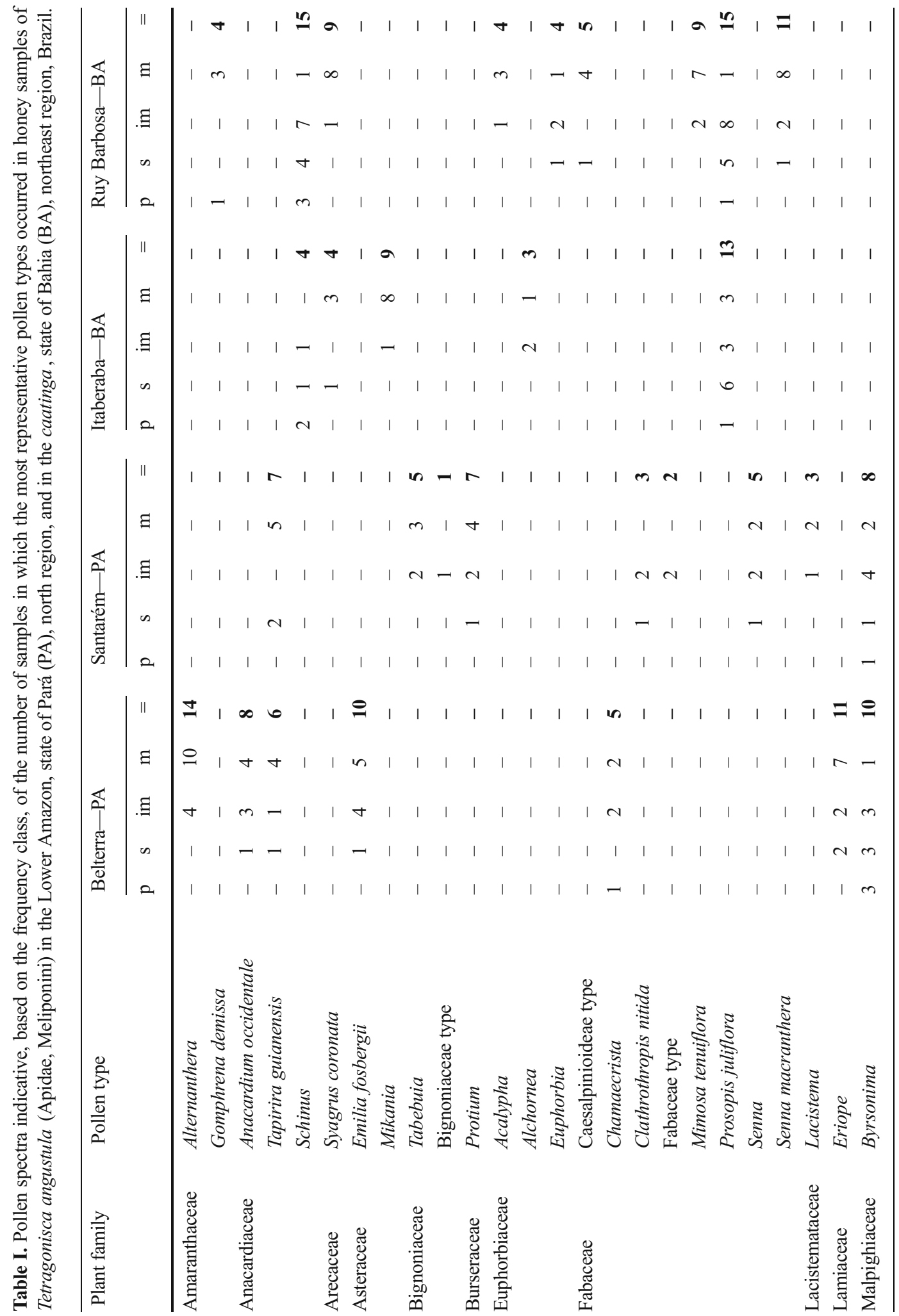




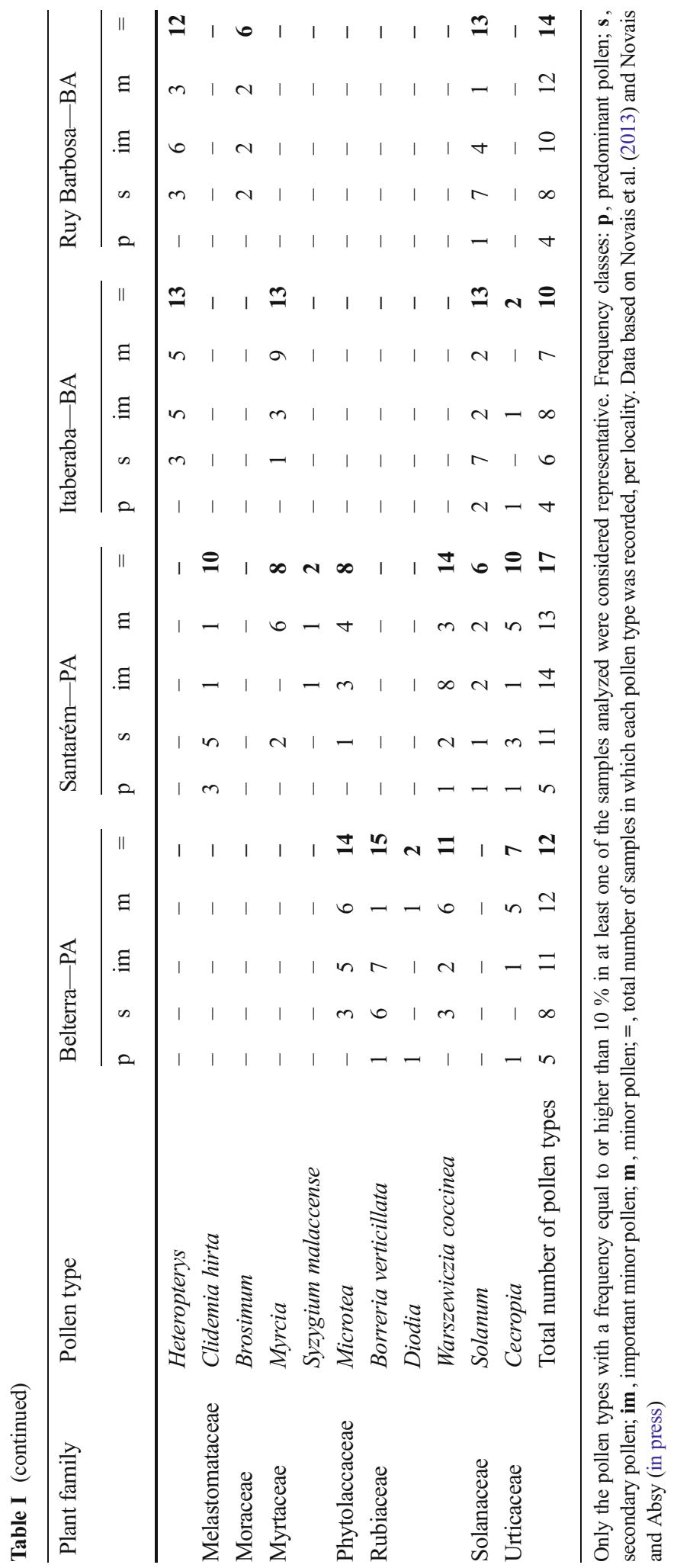




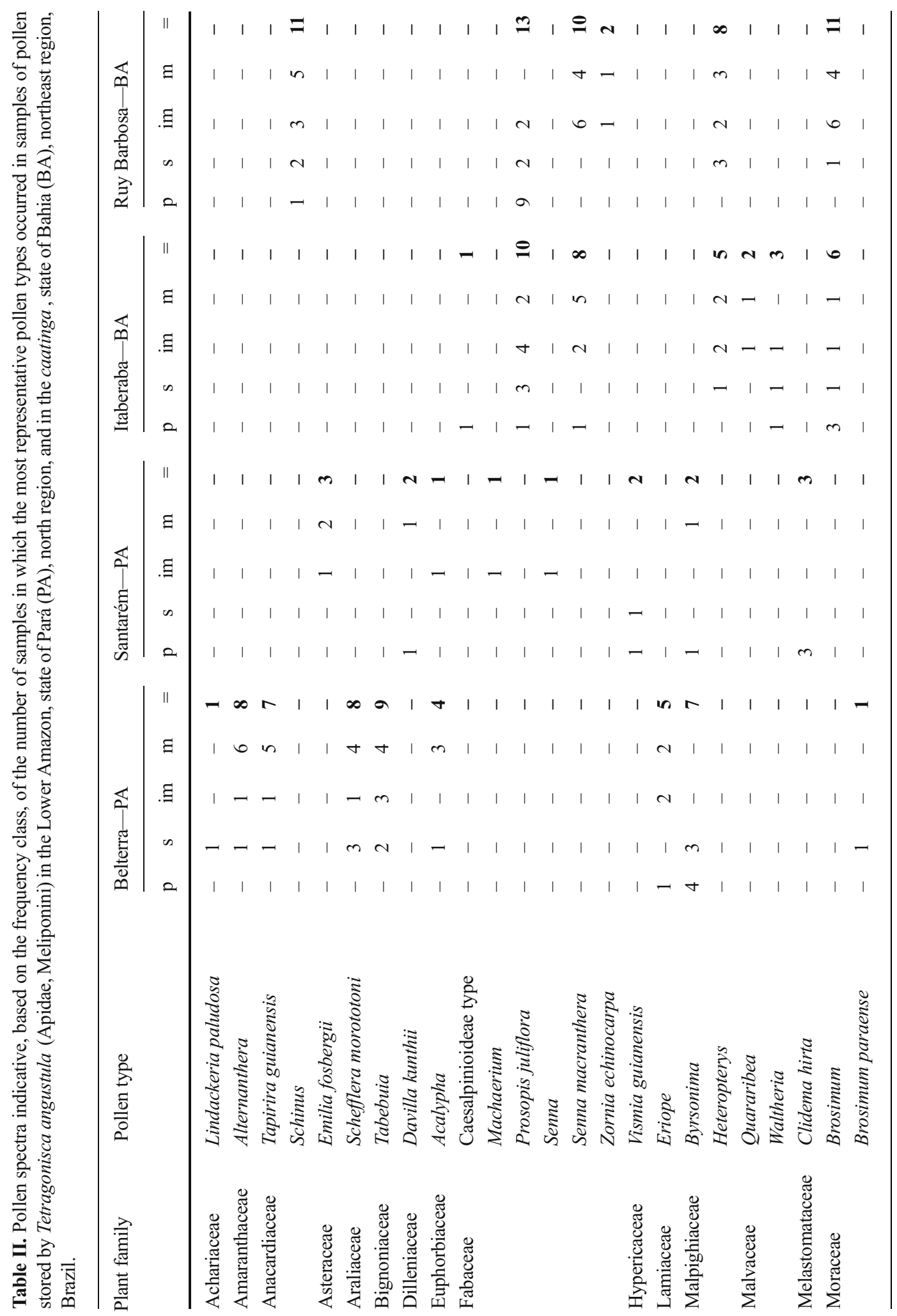




\subsection{Pollen groups based on the cluster analysis}

The groups obtained by the cluster analysis of the pollen spectra of the honey samples were more homogeneous than those obtained with the pollen spectra of the pollen stored samples (Figures 4 and 5).

The first phenogram obtained (cophenetic coefficient 0.94 , Figure 4) initially formed two distinct groups, gathering all the samples from the Lower Amazon in group A and all samples from the caatinga in group B. However, the level of similarity of group A was lower than that of group B (Figure 4).

The cluster analysis also revealed the formation of subgroups within the wider groups (A and B), gathering the samples per municipality (Figure 4). In crescent order of similarity, the following subgroups were formed: $\mathrm{C}$ (gathering the samples from Belterra), D (Santarém), E (Ruy Barbosa), and $\mathrm{F}$ (Itaberaba), the last with a level of similarity higher than 0.70 (Figure 4 ).

In group $\mathrm{A}$, the predominant and/or secondary pollen types shared by subgroups $\mathrm{C}$ and $\mathrm{D}$ were Byrsonima, Cecropia, Microtea, Tapirira guianensis, and $W$. coccinea (Figure 4). Of these types, only $T$. guianensis was not among the most frequent pollen types in the honey samples from the Lower Amazon (Figure 4). The pollen types Heteropterys, P. juliflora, Schinus, and Solanum were shared as predominant and/or secondary pollen types in the samples gathered in group B, thus characterizing this cluster (Figure 4). These same pollen types were among those with the highest occurrence in the honey samples from the caatinga (Figure 2).

The second phenogram (cophenetic coefficient 0.96, Figure 5), obtained from the cluster analysis with the data from the pollen stored samples, shows less-consistent groups than those obtained from the cluster analysis with the data from the honey samples (Figure 4). Two main groups can be observed: group A, gathering the samples from the Lower Amazon; and group B, gathering the samples from the caatinga (Figure 5). However, these groups showed a low similarity level $(<0.4)$, especially group A $(<0.1)$ (Figure 5). 
a

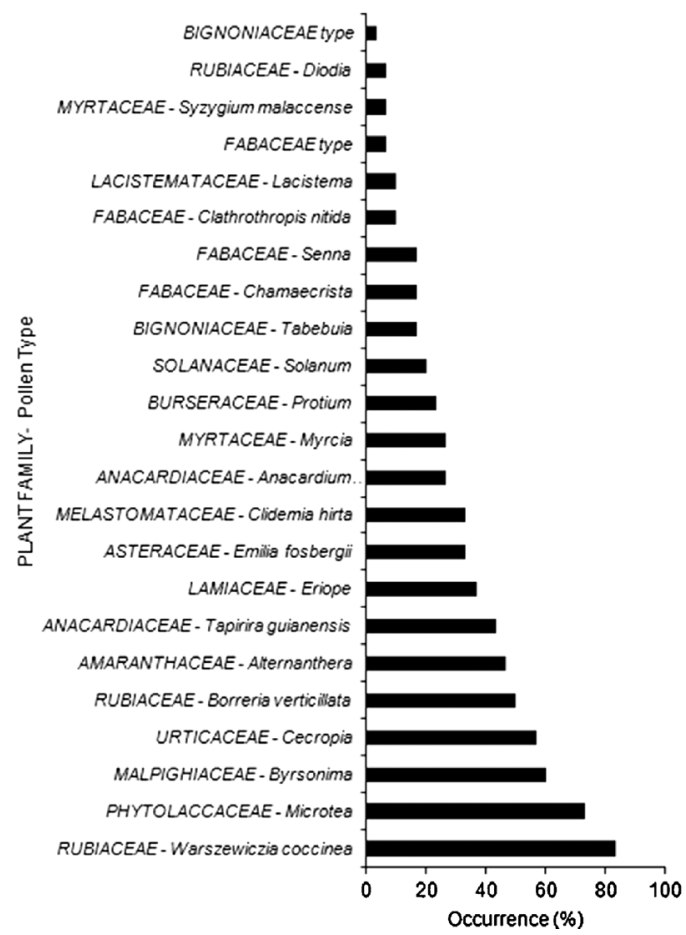

b

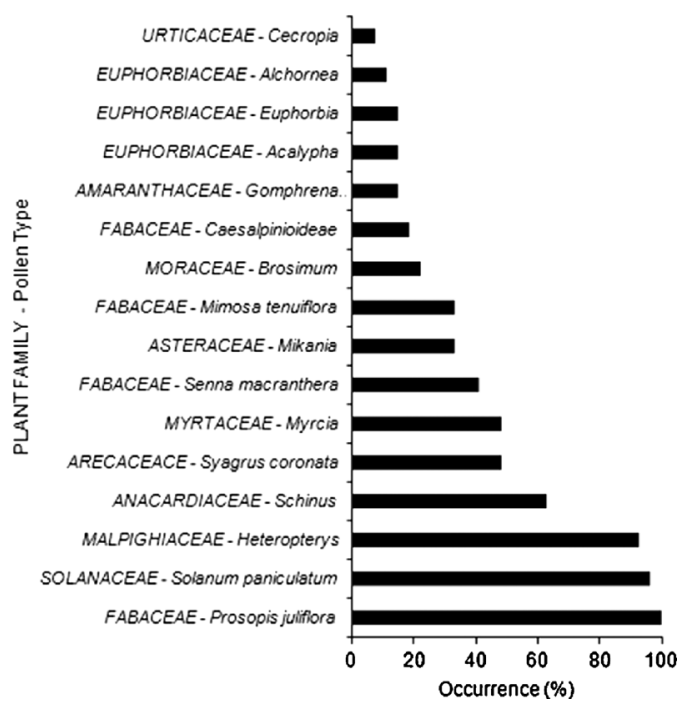

Figure 2. Occurrence (\%) of pollen types in 57 samples of honey produced by Tetragonisca angustula (Apidae, Meliponini) in Amazonian areas (a ) and semiarid areas (b ) of Brazil. Only the pollen types with a frequency equal to or higher than $10 \%$ in at least one of the samples analyzed are represented in this diagram.

From these two main groups (A and B), two additional sub-groups were formed (Figure 5); however, these sub-groups did not show a significant geographic discrimination, in contrast to the first phenogram (Figure 4). In crescent order of similarity level, the subgroups $\mathrm{C}$ and $\mathrm{D}$ were generated for the Lower Amazon, and the subgroups $\mathrm{E}$ and $\mathrm{F}$ were generated for the caatinga (Figure 5). Subgroup C gathered, with low similarity $(<0.3)$, only three pollen stored samples from Santarém, in which the predominant pollen types were $C$. hirta and D. kunthii. Subgroup D gathered samples from Belterra and Santarém. Within this subgroup, smaller clusters were generated, gathering, for example, samples exclusive to Santarém (clusters G and $\mathrm{J}$ ) and to Belterra ( $\mathrm{H}$ and $\mathrm{I}$ ). Subgroup E gathered pollen stored samples from the two caatinga areas, whereas subgroup F gathered only the sample collected in Itaberaba in January 2011, with Caesalpinioideae type as the predominant pollen (Figure 5). Within subgroup E, cluster K stood out for gathering 10 samples exclusively from Ruy Barbosa at a similarity level higher than 0.7. The predominant pollen types in this cluster (K) were P. juliflora, Schinus, and Solanum (Figure 5). Clusters L and $\mathrm{M}$ gathered samples from both Itaberaba and Ruy Barbosa, with emphasis on the pollen type Brosimum (Figure 5).

The predominant and/or secondary pollen types shared by more than one subgroup of group A were Byrsonima ( $\mathrm{G}$ and $\mathrm{H}$ ), Cecropia (G, H, and I), and C. hirta (C and G) (Figure 5). Of these types, Cecropia was among the most frequent pollen types in the pollen stored samples from the Lower Amazon (Figure 3). In contrast, Brosimum (K, $\mathrm{L}$, and $\mathrm{M})$, Heteropterys ( $\mathrm{K}$ and $\mathrm{M})$, P. juliflora (K, L, and M), Schinus (K and $\mathrm{M})$, and Solanum (K, L, and M) were the pollen types most shared by subgroups of group 
a

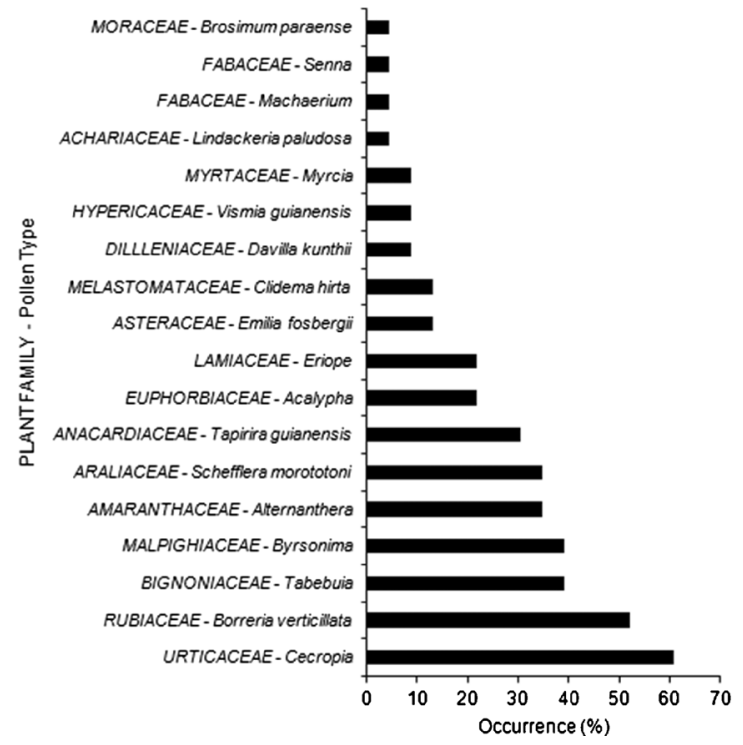

b

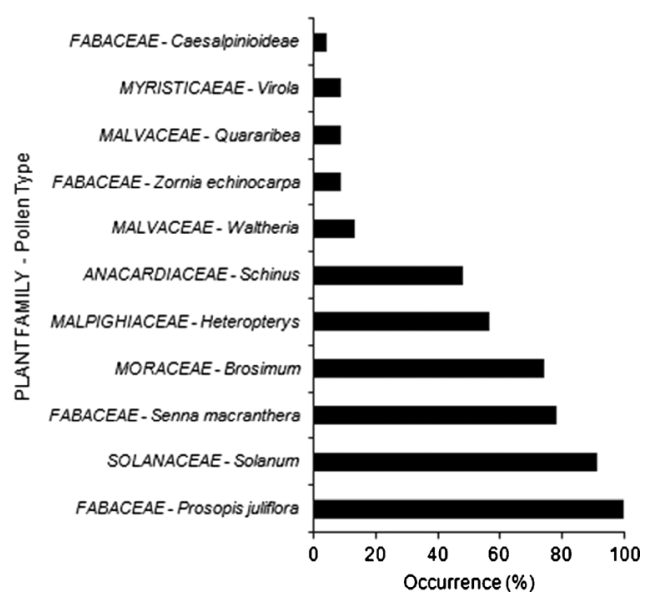

Figure 3. Occurrence (\%) of pollen types in 46 samples of pollen stored by Tetragonisca angustula (Apidae, Meliponini) in Amazonian areas (a) and semiarid areas (b ) of Brazil. Only the pollen types with a frequency equal to or higher than $10 \%$ in at least one of the samples analyzed are represented in this diagram.

B (Figure 5). Of these, only Schinus was not among the pollen types with the highest occurrence in the pollen stored by T. angustula in the caatinga (Figure 3).

Concerning the climatic data from the study sites, we noted that in Belterra, five months were considered dry (September and November 2010; August, September, and December 2011) (Figure 6). In Santarém, only October 2010 and September 2011 were dry. In contrast, in Itaberaba, all the months of 2011 were dry except November (Figure 6). In the honey samples from Santarém, the cluster formed by the samples collected between February and April 2011 represents the peak of precipitation in this region (Figures 4 and 6) and the period of dominance of the pollen type $C$. hirta (Online Resource 1). In contrast, the pollen stored samples from Belterra in the months of September and October 2010, in addition to those of June, August, and September 2011, formed a cluster representing the months that were dry or had low precipitation (Figures 5 and 6), and these samples were dominated by the pollen types Byrsonima, $B$. verticillata, Cecropia, Schefflera morototoni (Araliaceae), and Tabebuia (Bignoniaceae) (Online Resource 2).

\section{DISCUSSION AND CONCLUSION}

Despite the high number of pollen types identified in both the honey and pollen stored samples, a few pollen types effectively contributed to the composition of the majority of the pollen spectra obtained. This finding corroborates previous palynological studies performed in areas of the Central Amazon involving species of Frieseomelitta, Melipona, Scaptotrigona, and Trigona (Marques-Souza et al. 1996, 2002; Marques-Souza 2010). In areas of caatinga in the northeast region of Brazil, a similar pattern was also observed in palynological works with species of Melipona, Scaptotrigona, and Tetragonisca (Alves et al. 2006; Novais et al. 2006; Santana et al. 2011).

In general, several pollen types were recorded in both the pollen stored and honey samples, such as Alternanthera, Byrsonima, Cecropia, Heteropterys, P. Juliflora, and Solanum; however, in a few cases, the order of abundance of these 


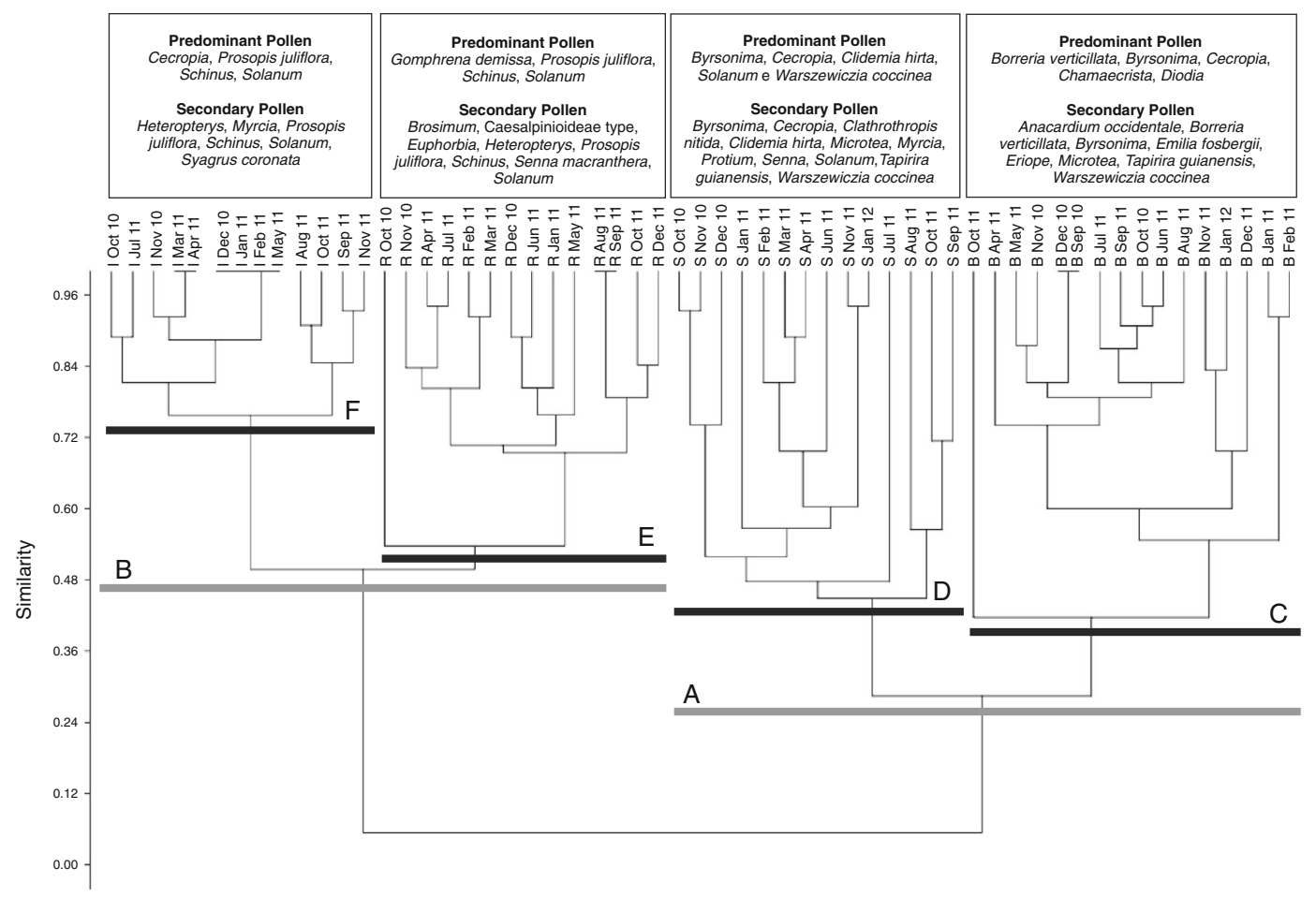

Figure 4. Phenogram generated from the cluster analysis, using the Dice similarity coefficient, of the pollen spectra of 57 samples of honey produced by Tetragonisca angustula (Apidae, Meliponini) in areas of the Lower Amazon (Belterra and Santarém, state of Pará) and of the semiarid region (Itaberaba and Ruy Barbosa, state of Bahia) in Brazil. The main clusters obtained are emphasized (letters $A-F)$ as well as the dominant pollen types ( $>45 \%)$ and accessory pollen types (16-45\%) characteristic of the groups. Cophenetic coefficient: 0.9378 .

genera changed. A similar trend was also observed by Imperatriz-Fonseca et al. (1984), who analyzed the food provisions (honey and pollen) of T. angustula in the state of São Paulo, southeast region of Brazil, and by Sosa-Nájera et al. (1994), who conducted research with $T$. angustula in the south of Mexico.

According to our studies and to data from the literature previously cited, some meliponine species prefer certain pollen types for certain periods of time. However, additional studies are required to evaluate if this is a real preference or simply arises from bees exploiting seasonally available pollen. In the case of T. angustula, Obregón et al. (2013) noted that the workers of a same colony usually tend to be consistent, visiting the same species and showing preferences for certain nectar sources, mainly for species that mass flowers. These preferences are related to the availability of food in the foraging radius of the meliponines, determining the extension of their trophic niche.

The cluster analysis here performed did not allow the establishment of well-defined groups based only on the climatic data from the study sites. However, assuming that the beginning, duration, and synchronization of the flowering process are related, although not exclusively, to climatic factors (Opler et al. 1976; Murphy and Lugo 1986), it is possible to presume that there is a direct relationship between climatic conditions and pollen spectra composition.

In arid and semiarid ecosystems, the relationship between flowering and precipitation is striking because, for most species, the flower buds generally start blossoming after the rains (Machado et al. 1997), changing the physiognomy of the caatingas. For tropical regions, Opler 


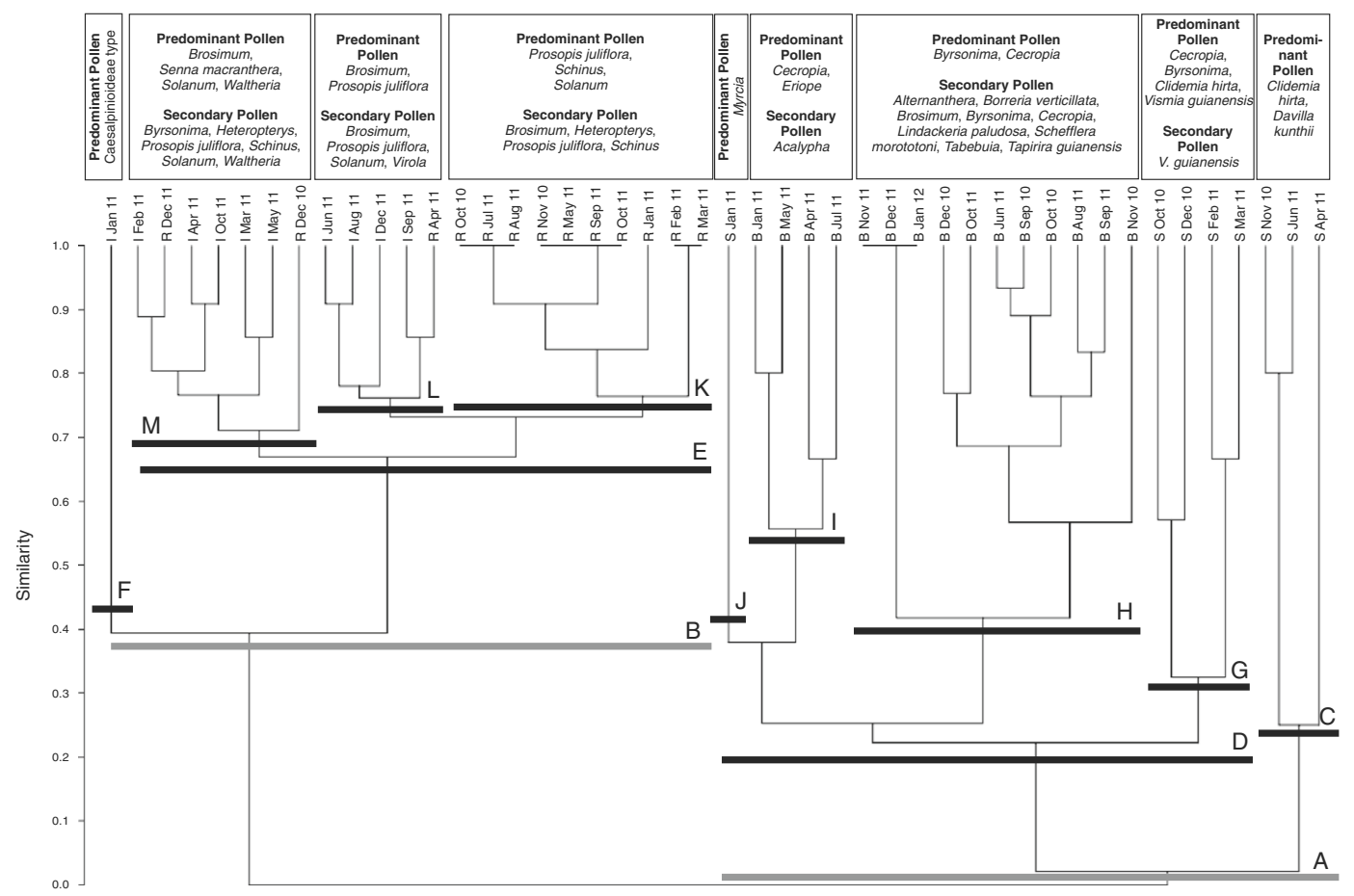

Figure 5. Phenogram generated from the cluster analysis, using the Dice similarity coefficient, of the pollen spectra of 46 samples of pollen stored by Tetragonisca angustula (Apidae, Meliponini) in areas of the Lower Amazon (Belterra and Santarém, state of Pará) and of the semiarid region (Itaberaba and Ruy Barbosa, state of Bahia) in Brazil. The 12 clusters obtained are emphasized (letters $A-M)$ as well as the dominant pollen types ( $>45 \%)$ and accessory pollen types (16-45\%) characteristic of the groupings. Cophenetic coefficient: 0.9615 .

et al. (1976) state that factors such as the reduction of water stress and the isolated decrease in temperature can break dormancy and, consequently, lead to the synchronized anthesis of several plant species. This synchronization favors cross-pollination, providing flower rewards that attract several pollinators (Opler et al. 1976).

The botanical families with predominant pollen types in the samples from the Amazonian region were Dilleniaceae, Fabaceae, Hypericaceae, Lamiaceae, Malpighiaceae, Melastomataceae, Myrtaceae, Rubiaceae, Solanaceae, and Urticaceae. Similar results were found by Rech and Absy (2011a, b) when working with meliponines of the genera Cephalotrigona, Partamona, Ptilotrigona, Scaura, Tetragonisca, and Trigona along the canal of the Negro River in the state of Amazonas. These results indicate the sharing of the same floral sources by different meliponines, although not necessarily during the same foraging period.

In the samples from the caatinga, the families with predominant pollen types were Amaranthaceae, Anacardiaceae, Fabaceae, Malvaceae, Moraceae, Solanaceae, and Urticaceae. These plant groups are cited in several studies of the bee flora in this semiarid area (Alves et al. 2006; Borges et al. 2006; Novais et al. 2006; Santos et al. 2006).

Roubik and Moreno (2013) state that the predominant pollen is often not an indication of the source of the nectar. This fact is evident when observing the presence of pollen types related to polleniferous species or genera (such as Brosimum, Cecropia, Clidemia, Solanum etc.) as the predominant pollen in honey samples. These pollen spectra provide information on the floral species 

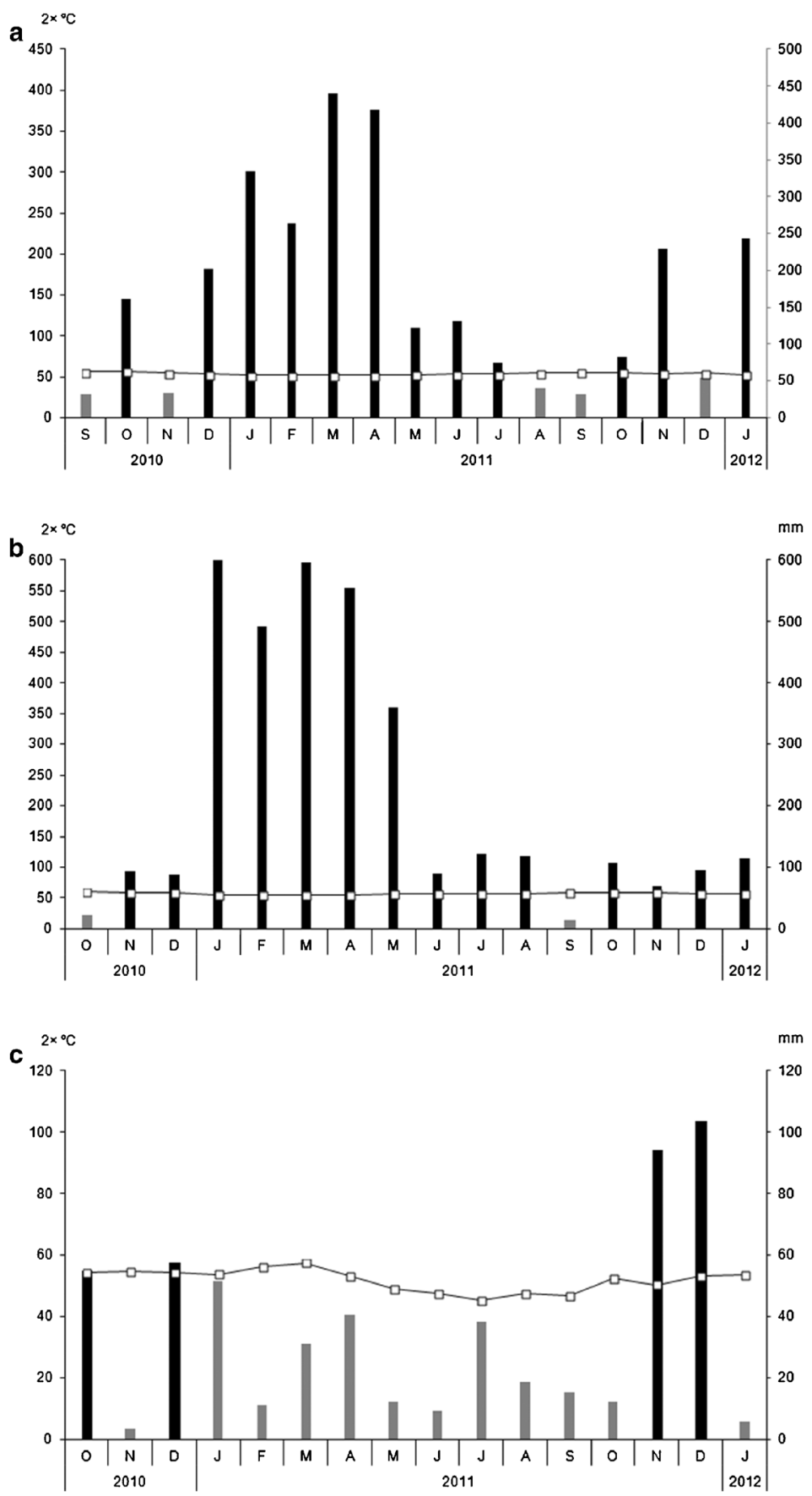

Figure 6. Climatic data obtained by INMET (2013) for the municipalities of Belterra (a), Santarém (b), and Itaberaba (c). A month was considered dry (emphasized in gray in the graphs) when the total precipitation (mm) was equal to or lower than twice the temperature $\left({ }^{\circ} \mathrm{C}\right)$, according to Bagnouls and Gaussen (1962).

that bees visit, but not necessarily the species that they collect nectar from.
The pollen spectra of the honey samples revealed a higher number of pollen types than the 
pollen spectra of the pollen stored samples. This finding possibly reflects the higher number of plants that $T$. angustula needs to visit to find nectar in both the Amazonian and the caatinga areas. Also, the extra plant species found in the honey samples could come from contamination after visiting nectar's flowers. In contrast, the protein need was supplied by a smaller array of plant species, although this pattern does not necessarily indicate a lower collection effort. The bees may have reduced foraging to a few species but visited a large number of flowers of those species in search of pollen.

The cluster analysis performed with honeys provided two distinct clusters based on the geographical origin of the samples. Results obtained from pollen stored presented lower similarity than that provided by honeys. We hypothesize the more homogeneous is the collection, the higher the similarity between samples. Ecological indices previously calculated by Novais and Absy (2013) and Novais et al. $(2013,2014)$ from the same data set discussed here showed higher values for evenness in honey samples than pollen stored. The more heterogeneous pattern of foraging recorded by pollen stored analysis is due to the concentrated harvest of pollen from certain plant species by $T$. angustula. On the other hand, the nectar harvest revealed low specificity and a more homogeneous pattern of foraging, resulting in high similarity between samples.

The pattern observed in the cluster analysis should not be considered as a rule, however. In fact, all foraging strategies are sensitive to increased competitive pressure (Biesmeijer and Slaa 2006), and we have not examined this point here. Brazil tends to present a gradient in number of species of plants and stingless bees from semiarid to Amazon forest areas, i.e., from dry to wet regions. The honey- and pollen-based clusters showed this when group samples were compared from Itaberaba/Ruy Barbosa and Santarém/Belterra, albeit with different similarity levels.

We found a slight difference in the number of pollen types recorded from Amazonian and caatinga sites, especially regarding honey samples. Honeys from Amazon presented more pollen types than honeys from dry areas. This fact could be related to differences in the nectar composition at the studied sites, mainly guided by climatic factors. In Costa Rica, Biesmeijer et al. (1999) observed that species of Melipona collected richer nectar at a dry climate site than at a humid climate site. However, other factors can also influence the foraging behavior of bees, such as specific need of colonies or interspecific competition. Further studies are required to clarify these points.

Based on the cluster analysis, we conclude the pollen data of the honey samples were more consistent in the grouping of samples analyzed per geographic region than the pollen data of the pollen stored samples. The climatic data did not allow a consistent grouping of the samples by study sites.

\section{ACKNOWLEDGMENTS}

We are extremely grateful to Carleandro Dias and Geancarlo Gouveia for authorizing the collection of samples within their private meliponaries. We are also grateful to the regional management of the Company for Agricultural Development of the State of Bahia (EBDA) for providing logistic support during the samplings in Bahia, to the direction of the Mãe Jovina School of the Agricultural Family for allowing access to the meliponary in Ruy Barbosa, to the Municipal Secretariat of Education of Santarém for authorizing the collections within the School of the Forest, to Bruno Henrique Andrade-Silva for contributing to the collections and to the processing of the samples, and to Leilton Damascena for providing the map shown here. We thank the Brazilian National Council for Scientific and Technological Development (CNPq) for partial funding of this research and for the scholarships granted to the authors of this study (processes 575747/2008-0, 143084/2009-7, 303557/2010-9, and 477127/2011-8).

\section{Comparaison des spectres de pollens récoltés par Tetragonisca angustula (Apidae, Meliponini) dans la basse vallée de l'Amazone (Nord du Brésil) et dans la Caatinga (Nord-Est du Brésil)}

analyse de cluster / indice de similarité de Dice / entomopalynologie / miel / mélissopalynologie / pollen stocké / abeille sans aiguillon 
Ein Vergleich der Pollenspektren von Tetragonisca angustula (Apidae, Meliponini) aus dem unteren Amazonas (Nordbrasilien) und der Caatinge (Nordostbrasilien)

\section{Clusteranalyse / Dice Ähnlichkeit / Entomopalynologie / Melissopalynologie / stachellose Bienen / Honig/ Pollenvorrat}

\section{REFERENCES}

Alves, R.M.O., Souza, B.A., Carvalho, C.A.L. (2006) Espectro polínico de amostras de mel de Melipona mandacaia Smith. 1863 (Hymenoptera-Apidae). Acta Sci. Biol. Sci. 28(1), 33-38

Bagnouls, F., Gaussen, H. (1962) Estação seca e índice xerotérmico. Boletim Geográfico 20 (169), 338-369. (translated into Portuguese by R. S. B. Santos)

Biesmeijer, J.C., Slaa, E.J. (2006) The structure of eusocial bee assemblages in Brazil. Apidologie 37, 240-258

Biesmeijer, J.C., Smeets, M.J.A.P., Richter, J.A.P., Sommeijer, M.J. (1999) Nectar foraging by stingless bees in Costa Rica: botanical and climatological influences on sugar concentration of nectar collected by Melipona . Apidologie 30, 43-55

Borges, R.L.B., Lima, L.C.L., Oliveira, P.P., Silva, F.H.M., Novais, J.S., Dórea, M.C., Santos, F.A.R. (2006) O pólen no mel do semi-árido brasileiro. In: Santos, F.A.R. (ed.) Apium Plantae, pp. 103-118. IMSEAR, Recife

Erdtman, G. (1960) The acetolysis method-a revised description. Sv. Bot. Tidskr. 54 (4), 561-564

Fisch, G., Marengo, J.A., Nobre, C.A. (1998) Uma revisão geral sobre o clima da Amazônia. Acta Amazonica $\mathbf{2 8}(2), 101-126$

Freitas, B.M., Imperatriz-Fonseca, V.L., Medina, L.M., Kleinert, A.M.P., Galetto, L., Nates-Parra, G., Quezada-Euán, J.J.G. (2009) Diversity, threats and conservation of native bees in the Neotropics. Apidologie 40, 332-346

Hammer, Ø., Harper, D. A. T., Ryan, P. D. (2001) PAST: Palaeontological Statistics software package for education and data analysis. Palaeontologia Electronica 4(1) [online] http:// palaeo-electronica.org/2001_1/past/issue1_01.htm (accessed on 17 April 13)

IBGE-Instituto Brasileiro de Geografia e Estatística. (2004) Mapa dos biomas brasileiros. IBGE, Rio de Janeiro. [online] http://www.ibge.gov.br (accessed on 2 May 13)

Imperatriz-Fonseca, V.L., Kleinert-Giovannini, A., Cortopassi-Laurino, M., Ramalho, M. (1984) Hábitos de coleta de Tetragonisca angustula angustula Latreille (Apidae, Meliponinae). Boletim de Zoologia da Universidade de São Paulo 8, 115-131

INMET-Instituto Nacional de Meteorologia. (2013) Banco de Dados Meteorológicos para Ensino e
Pesquisa [online] http://www.inmet.gov.br/portal/ index.php?r=bdmep/bdmep (accessed on 21 April 13)

Louveaux, J., Maurizio, A., Vorwohl, G. (1978) Methods of melissopalynology. Bee World 59(4), 139-157

Machado, I.C., Barros, L.M., Sampaio, E.V.S.B. (1997) Phenology of caatinga species at Serra Talhada, PE, Northeastern Brazil. Biotropica 29(1), 57-68

Maia-Silva, C., Silva, C.I., Hrncir, M., Queiroz, R.T., Imperatriz-Fonseca, V.L. (2012) Guia de Plantas Visitadas por Abelhas na Caatinga. Fundação Brasil Cidadão, Fortaleza

Marques-Souza, A.C. (2010) Ocorrência do pólen de Podocarpus sp. (Podocarpaceae) nas coletas de Frieseomelitta varia Lepeletier 1836 (Apidae: Meliponinae) em uma área de Manaus, AM, Brasil. Acta Bot. Bras. 24, 558-566

Marques-Souza, A.C., Moura, C.O., Nelson, B.W. (1996) Pollen collected by Trigona williana (Hymenoptera: Apidae) in Central Amazonia. Rev. Biol. Trop. 44(2), 567-573

Marques-Souza, A.C., Miranda, I.P.A., Moura, C.O., Rabelo, A., Barbosa, E.M. (2002) Características morfológicas e bioquímicas do pólen coletado por cinco espécies de meliponíneos da Amazônia Central. Acta Amazonica 32, 217-229

McCune, B., Grace, J. (2002) Analysis of Ecological Communities. MjM Software, Gleneden Beach

Murphy, P.G., Lugo, A.E. (1986) Ecology of tropical dry forest. Annu. Rev. Ecol. Syst. 17, 67-88

Novais, J.S., Absy, M.L. (2013) Palynological examination of the pollen pots of native stingless bees from the Lower Amazon region in Pará, Brazil. Palynology $37(2), 218-230$

Novais, J.S., Lima, L.C.L., Santos, F.A.R. (2006) Espectro polínico de méis de Tetragonisca angustula Latreille, 1811 coletados na caatinga de Canudos, Bahia, Brasil. Magistra 18(4), 257-264

Novais, J.S., Absy, M.L., Santos, F.A.R. (2013) Pollen grains in honeys produced by Tetragonisca angustula (Latreille, 1811) (Hymenoptera: Apidae) in tropical semi-arid areas of north-eastern Brazil. ArthropodPlant Interactions 7 (6), 619-632

Novais, J.S., Absy, M.L., Santos, F.A.R. (2014) Pollen types collected by Tetragonisca angustula (Hymenoptera: Apidae) in dry vegetation in Northeastern Brazil. Eur. J. Entomol. 111 (1), 25-34

Novais, J.,S., Absy, M. L. (in press) First melissopalynological records in honeys from Tetragonisca angustula (Latreille, 1811) in Lower Amazon, Brazil: pollen spectrum and concentration. J. Apic. Res.

Obregón, D., Rodríguez, C.Á., Chamorro, F.J., Nates-Parra, G. (2013) Botanical origin of pot-honey from Tetragonisca angustula Latreille in Colombia. In: Vit, P., Pedro, S.R.M., Roubik, D. (eds.) Pot-Honey: A Legacy of Stingless Bees, pp. 337-346. Springer, New York

Opler, P.A., Frankie, G.W., Baker, H.G. (1976) Rainfall as a factor in the release, timing, and synchronization of 
anthesis by tropical trees and shrubs. J. Biogeogr. 3, 231-236

Prado, D. (2003) As caatingas da América do Sul. In: Leal, I.R., Tabarelli, M., Silva, J.M.C. (eds.) Ecologia e conservação da caatinga, pp. 3-73. Editora Universitária da UFPE, Recife

Ramalho, M., Imperatriz-Fonseca, V.L., KleinertGiovannini, A., Cortopassi-Laurino, M. (1985) Exploitation of floral resources by Plebeia remota Holmberg (Apidae, Meliponinae). Apidologie 16 (3), 307-330

Rech, A.R., Absy, M.L. (2011a) Pollen sources used by species of Meliponini (Hymenoptera: Apidae) along the Rio Negro channel in Amazonas, Brazil. Grana 50 (2), 150-161

Rech, A.R., Absy, M.L. (2011b) Pollen storages in nests of bees of the genera Partamona, Scaura and Trigona (Hymenoptera, Apidae). Rev. Bras. Entomol. 55(3), 361-372
Roubik, D., Moreno, P.J.E. (2013) How to be a bee-botanist using pollen spectra. In: Vit, P., Pedro, S.R.M., Roubik, D. (eds.) Pot-honey: a legacy of stingless bees, pp. 295-314. Springer, New York

Santana, A.L.A., Fonseca, A.A.O., Alves, R.M.O., Carvalho, C.A.L., Melo, P.A., Silva, E.S., Souza, B.A., Jesus, J.N., Sodré, G.S. (2011) Tipos polínicos em amostras de méis de abelhas sem ferrão de municípios do semiárido baiano. Magistra 23 (3), 134-139

Santos, F.A.R., Oliveira, J.M., Oliveira, P.P., Leite, K.R.B., Carneiro, C.E. (2006) Plantas do semi-árido importantes para as abelhas. In: Santos, F.A.R. (ed.) Apium Plantae, pp. 61-86. IMSEAR, Recife

Sosa-Nájera, M.S., Martínez-Henández, E., LozanoGarcía, M.S., Cuadriello-Aguiar, J.I. (1994) Nectaropolliniferous sources used by Trigona (Tetragonisca) angustula in Chiapas, southern México. Grana 33 (4), 225-230 